\title{
Wpływ oparów metalicznych na spawanie łukowe, część 3: Modelowanie łuku spawalniczego - wyniki. Dymy spawalnicze
}

\author{
The effects of metal vapour in arc welding, \\ part 3: Modelling of welding arc - results. Welding fumes
}

\section{Streszczenie}

W tej części artykułu przedstawiono wyniki oraz przewidywania obliczeniowego modelowania łuków spawalniczych, a także wpływ oparów metalicznych na parametry łuku. Omówiono powstawanie pyłów wpływających na zdrowie spawacza. Podsumowanie artykułu może być przydatne do tworzenia oprogramowania procesora źródła do sterowania stabilnością łuku, funkcjami ułatwiającymi spawanie i korekty błędów spawacza (reklamowanych w Australii jako oprogramowanie urządzeń, myślących za spawacza) [198].

\section{Modelowanie łuków spawalniczych}

Obliczeniowe modelowanie łuków spawalniczych przeprowadza się przy użyciu sprzężonych równań różniczkowych cząstkowych $(1 \div 7)$ [cz. 2 art.] wyrażających zasady zachowania: masy, pędu, energii oraz ładunku. Uwzględnienie w obliczeniach granicy pomiędzy elektrodami a plazmą, wymaga odpowiedniego dobrania wewnętrznych warunków granicznych. Ostatnio pojawiło się dużo prac na temat obliczeniowego modelowania plazm termicznych i wszystkie one dają dobry obraz stosowanych technik [5, 84, 134, 180].

Większość modeli obliczeniowych łuku dotyczy spawania GTAW, pomimo że spawanie GMAW jest częściej stosowane. Powód jest ten sam, jaki podano przy opisie doświadczeń - opis procesu spawania GTAW jest znacznie prostszy. W porównaniu z GMAW można założyć, że łuk będzie stabilny i nie rozpatruje się przejścia kropli, a katoda może być traktowana jako źródło emisji termoelektronów.

Anthony B. Murphy - CSIRO Materials Science and Engineering, Australia.
Modelowanie, które uwzględnia wpływ oparów metalicznych, dotyczyło głównie procesu GTAW. Dopiero ostatnio zaczęto rozpatrywać ich znaczenie w modelowaniu łuku GMAW. Przeczy to obserwacjom, że dużo więcej oparów metalicznych powstaje w łuku GMAW.

\section{Modelowanie łuków w spawaniu GTAW}

Gu. stworzył model, w którym badał wpływ oparów krzemu odparowujących $z$ anody na właściwości łuku argonowego [109, 129, 166]. Właściwości emisji promieniowania określił przy użyciu metody statystycznej Crama [138]. We wcześniejszej pracy zakładał, że opary krzemu równomiernie rozkładały się w plazmie, co doprowadziło do spadku temperatury wskutek wzrostu emisji promieniowania [109]. Model został następnie ulepszony i zawierał równanie na zachowanie masy składników dla oparów krzemu, początkowo z oszacowaną temperaturą powierzchni anody, a następnie $z$ temperaturą anody obliczoną $z$ uwzględnieniem przepływu w ciekłym metalu [129, 130, 166]. W celu uwzględnienia dyfuzji zastosowano metodę współczynnika dyfuzji quasi-binarnej. Szybkość odparowywania krzemu z ciekłej anody została określona przy założeniu, że dyfuzja masy przez zastygłą 
warstwę gazową, sąsiadującą z anodą, ograniczała tę szybkość. W obliczeniach uwzględniono wpływ anody oraz przepływ ciekłego metalu.

Wyniki podano dla prądu o natężeniu $200 \mathrm{~A}$ i łuku długości $10 \mathrm{~mm}$ parametrów odpowiednich dla spawania łukowego [129, 166]. Kiedy temperatura ciekłego krzemu była obliczana bez uwzględniania oparów, szybkość odparowywania krzemu wynosiła ok. 3,5 mg $\mathrm{s}^{-1}$, a ułamek masowy krzemu miał wartość $8 \%$ na osi blisko anody, zmniejszając się gwałtownie do mniej niż 0,2\% w odległości mniejszej niż $1 \mathrm{~mm}$ od anody [129]. Obecność oparów krzemu zwiększyła przewodność elektryczną w obszarach poza osią, blisko anody, obniżając gęstość prądu oraz gęstość strumienia ciepła w kierunku anody. Wskutek tego obniżyła się temperatura powierzchni ciekłej anody, a także zmniejszyło się napięcie łuku.

Wstępne wyniki podano także dla prądu o natężeniu $600 \mathrm{~A}$ i łuku o długości 183 mm, czyli parametrów stosowanych w obróbce minerałów [129, 130]. W tym wypadku silna emisja promieniowania związana z większym stężeniem krzemu spowodowała obniżenie temperatury łuku na tyle, by obniżyć jego przewodność elektryczną i zarazem doprowadzić do wzrostu napięcia łuku z powodu obecności oparów metalicznych. Wyniki te pokazano na rysunku 16 . Można zauważyć, że nawet bardzo niskie stężenie krzemu, wynoszące mniej niż $0,01 \%$ mas., obniża napięcie z powodu podwyższonej przewodności elektrycznej. Zjawiska związane z promieniowaniem są istotne tylko w przypadku stężenia powyżej ok. 0,1\%. Zmniejszenie napięcia z powodu zwiększonej przewodności elektrycznej, spowodowanej przez obecność oparów metali, towarzyszy zazwyczaj stężeniu masowemu oparów krzemu dochodzącemu do 5\% powyżej 5\% chłodzenie radiacyjne prowadzi do zwiększenia napięcia.

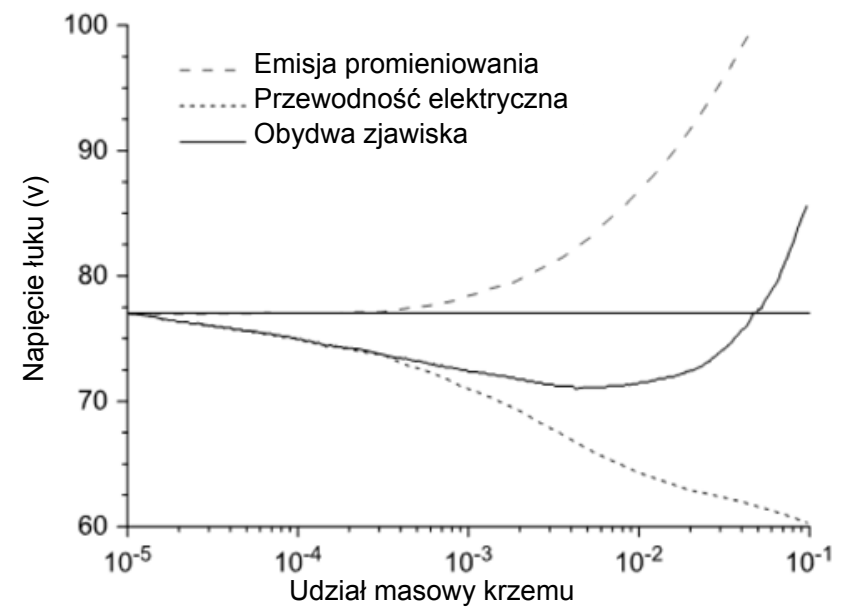

Rys. 16. Obliczone napięcie kolumny łuku argonowego długości 183 mm przy 600 A i różnych stężeniach krzemu. Uwzględniono: wpływ krzemu tylko na przewodność elektryczną, tylko na współczynnik emisji promieniowania oraz oba parametry równocześnie [129, 130] Fig. 16. Calculated arc column voltage for a $600 \mathrm{~A}, 183 \mathrm{~mm}$ long arc in argon, for different uniform concentrations of silicon. Results taking into account the influence of silicon on only the electrical conductivity, on only the radiative emission coefficient and on both parameters are shown $[129,130]$
Menart i Lin [156] oraz Zhao [157] modelowali łuk argonowy GTAW z oparami miedzi odparowanymi $z$ anody. Obszar anody nie był traktowany samoistnie, zakładano najpierw konkretną temperaturę powierzchni i dopiero wyznaczano ciśnienie oparów miedzi. Zhao posłużył się przybliżeniem współczynnika dyfuzji binarnej, który jest dokładny jedynie w temperaturze, w której zarówno miedź, jak i argon nie są zjonizowane - zawyża tym samym prędkość dyfuzji. Z kolei Menart i Lin użyli nieco dokładniejszego przybliżenia lepkości. Osiągnęli ułamek masowy oparów miedzi na poziomie ok. $0,1 \%$ blisko anody, który miał wpływ na obniżenie temperatury w tym obszarze. [Zagadnienia te omówiono szerzej w cz. 2 art.].

Gonzalez badał wpływ oparów żelaza w spawaniu łukowym GTAW z anodą z żelaza [159]. Temperaturę na powierzchni anody obliczył bez uwzględniania przepływu w jeziorku metalu. Posłużył się przybliżoną wartością współczynnika dyfuzji binarnej, więc prędkości dyfuzji oparów metalu i tym samym stężenia będą zawyżone. Przewidział, że stężenia molowe oparów żelaza osiągną do 7\% na osi w sąsiedztwie anody przy natężeniu prądu $200 \mathrm{~A}$ oraz do $60 \%$ w przypadku łuku argonowego przy $300 \mathrm{~A}$, zmniejszając się do odpowiednio $1 \%$ i $5 \%$ w odległości $2 \mathrm{~mm}$ nad anodą. Opary metaliczne doprowadziły do znaczącego ochłodzenia łuku z powodu wzrostu emisji promieniowania. Doprowadziło to do spadku w strumieniu ciepła w kierunku anody i do zmniejszenia głębokości obszaru anody w temperaturze powyżej punktu topnienia żelaza.

Gonzalez użył podobnej metody w modelowaniu argonowego łuku GTAW z anodą z żelaza przy 90 A [63]. Przewidywane stężenie masy oparów wyniosło w tym przypadku jedynie $0,7 \%$ w odległości $1 \mathrm{~mm}$ ponad anodą, zmniejszając się do $0,2 \%$ w obszarze położonym $3 \mathrm{~mm}$ ponad nią. Jak wskazywano w części 1 artykułu na rysunku 2, przewidywane temperatury były zgodne z obliczeniami spektroskopowymi dla promienia mniejszego od $3 \mathrm{~mm}$ z rozbieżnością pojawiającą się na większych promieniach. Okazało się, że obecność oparów metalicznych obniżyła temperaturę o $1500 \mathrm{~K}$.

Lago badał wpływ oparów miedzi, żelaza i aluminium w łuku GTAW [158]. On także nie modelował przepływu w jeziorku metalu, lecz posłużył się ciśnieniem oparów żelaza na $1000 \mathrm{~K}$, jako warunkiem granicznym na powierzchni anody. Dyfuzja oparów żelaza została uwzględniona za pomocą przybliżenia lepkości. Porównał dwa łuki argonowe przy 200 A - jeden w obecności oparów metali, a drugi bez. Stężenie oparów żelaza blisko anody było bardzo wysokie, powyżej 40\% (mol.), lecz zmniejszało się gwałtownie do mniej niż $1 \%$ w odległości ok. $1 \mathrm{~mm}$ ponad anodą. Obecność oparów żelaza podniosła napięcie o 1,5 V, z powodu schłodzenia łuku spowodowanego zwiększonymi stratami radiacyjnymi, więc proporcjonalnie do tego zmniejszyło się również natężenie prądu. Kiedy całkowity strumień ciepła w kierunku anody zmniejszył się z powodu obecności oparów metalicznych, gęstość strumienia ciepła na osi była prawie dwukrotnie 
większa, co wynika z wpływu temperatury i stężenia na przewodność elektryczną. Przewodność elektryczna wzrosła z powodu obecności oparów metalu. Jednak na większych promieniach wpływ niższej temperatury miał większy wpływ niż wzrost przewodności elektrycznej w danej temperaturze $z$ powodu obecności oparów metalicznych.

Tashiro badał wpływ oparów żelaza na łuk w helu w spawaniu TIG [149]. W bardzo uproszczonym obliczeniu założył jednakowe stężenie oparów żelaza w całym łuku. Przewidział niższą temperaturę łuku spowodowaną stratami na promieniowanie i zmianami w przewodności elektrycznej oraz mniejszą gęstość strumienia ciepła w kierunku anody dla molowego stężenia oparów $5 \div 30 \%$.

Yamamoto obliczył wpływ oparów żelaza na łuki spawalnicze TIG w helu i argonie [160]. Główną zaletą jego badań było to, że model badawczy uwzględniał przepływ w jeziorku metalu, co pozwoliło na dokładniejsze określenie temperatury powierzchni i lepsze oszacowanie ciśnienia oparów na powierzchni jeziorka. Posłużył się m.in. przybliżeniem lepkości, by uwzględnić dyfuzję oparów metalu. Jak można zaobserwować na rysunku 17, okazało się, że stężenie oparów metalu w łuku przy natężeniu prądu 150 A było znacznie większe dla helu niż argonu. Podano wyniki 20 s po zajarzeniu łuku. Okazało się, że stężenie oparów zwiększyło się gwałtownie w ciągu pierwszych $5 \mathrm{~s}$, a następnie powoli osiągnęło stan stały [181]. Wyniki pokazują, jak ważna jest temperatura jeziorka w określeniu stężenia oparów metalicznych. Temperatura jest o ok. $500 \mathrm{~K}$ wyższa dla helu, ale prowadzi to do wzrostu w maksymalnym stężeniu molowym oparów żelaza z $0,2 \%$ do $7,0 \%$, co wskazuje na potrzebę dokładnego określenia temperatury jeziorka.

Wpływ oparów żelaza na gęstość prądu i gęstość strumienia cieplnego na powierzchni anody, będącej materiałem roboczym pokazano na rysunku 17 , zostały omówione przez Murphy'ego [168]. Stężenie oparów żelaza w łuku argonowym było zbyt niskie, by mieć wpływ na właściwości plazmy. Gęstość strumienia ciepła i gęstość prądu na osi, były o połowę mniejsze w łuku i osłonie helu. Było to spowodowane głównie wzrostem przewodności elektrycznej w niższej temperaturze, co znaczyło, że więcej prądu mogło przepłynąć przez chłodniejsze obszary na większych promieniach, prowadząc do mniejszej gęstości prądu blisko anody, a to z kolei wpłynęło na gęstość strumienia ciepła. Obecność oparów metalu wpłynęła także na zmniejszenie temperatury łuku w osłonie helu blisko anody. Przypisano to zwiększonej emisji promieniowania, a także zmniejszeniu się grzania z powodu niższej gęstości prądu. Napięcie łuku zmalało z 19,9 V dla łuku w czystym helu do 18,5 V, gdy uwzględniono obecność oparów metalicznych.

W następnych pracach Yamamoto oraz Tanaka badali wpływ kierunku przepływu w jeziorku na stężenie oparów w łuku [181, 182]. Porównali materiały ze stali nierdzewnej o niskiej i wysokiej zawartości

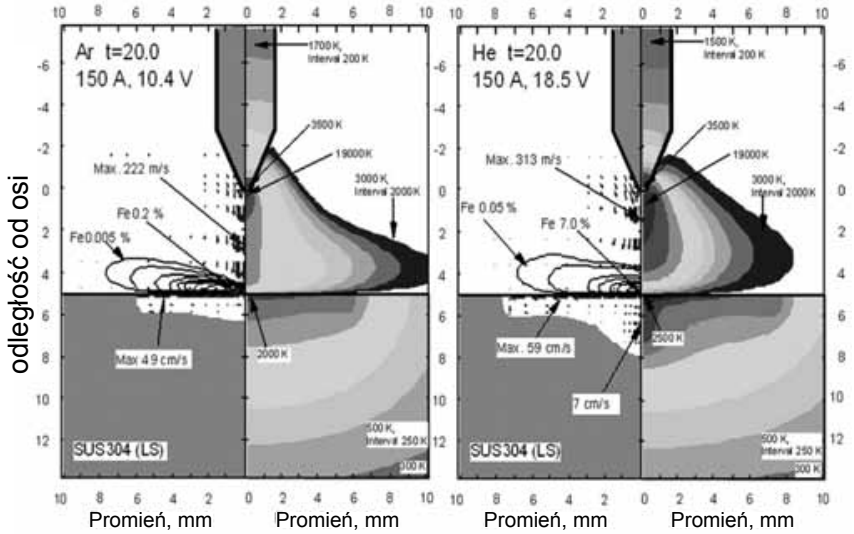

Rys. 17. Rozkład temperatury (po prawej stronie każdego grafu), rozkład części molowej oparów żelaza oraz wektory prędkości (lewa strona każdego grafu) w łuku i elektrodach w łuku spawalniczym GTAW przy $150 \mathrm{~A}$ w osłonie argonu i helu. Wyniki podano dla anod ze stali nierdzewnej 304 po 20 s pracy. Jeden stopień skali koloru odpowiada zmianie temperatury o: $2000 \mathrm{~K}$ w łuku, $200 \mathrm{~K} \mathrm{w}$ katodzie wolframowej i $250 \mathrm{~K}$ w anodzie. W każdym przypadku podano maksymalne wartości udziału molowego oparów żelaza oraz napięcie łuku [160]

Fig. 17. Temperature distribution (on the right-hand side of each plot) and iron vapour mole fraction distribution and velocity vectors (on the left-hand side of each plot) in the arc and electrodes for 150 A GTAW arcs in argon and helium. Results are given for a 304 stainless steel anode after $20 \mathrm{~s}$ of operation. The temperature interval is $2000 \mathrm{~K}$ in the arc, $200 \mathrm{~K}$ in the tungsten cathode and $250 \mathrm{~K}$ in the anode. The maximum values of the iron vapour mole fraction are given, as is the arc voltage in each case [160]
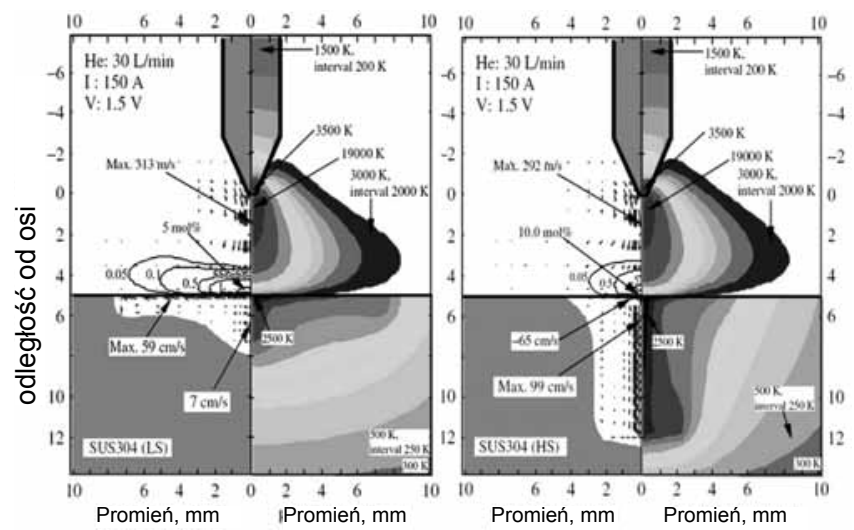

Rys. 18. Rozkład temperatury (po prawej stronie każdego grafu), rozkład części molowej oparów żelaza oraz wektory prędkości (lewa strona każdego grafu) w łuku i elektrodach w łuku spawalniczym GTAW przy $150 \mathrm{~A}$ w osłonie helu, po 20 s pracy. Wyniki podane są dla anod ze stali nierdzewnej 304 o niskiej zawartości siarki (lewa strona) i wysokiej zawartości siarki (prawa strona). Jeden stopień skali koloru odpowiada zmianie temperatury o: 2000 $\mathrm{K}$ w łuku, $200 \mathrm{~K}$ w katodzie wolframowej i $250 \mathrm{~K}$ w anodzie. W każdym przypadku podano maksymalne wartości ułamka molowego oparów żelaza. Reprodukcja za zgodą John Wiley and Sons [181] Fig. 18. Temperature distribution (on the right-hand side of each plot) and iron vapour mole fraction distribution and velocity vectors (on the left-hand side of each plot) in the arc and electrodes for 150 A GTAW arcs in helium after $20 \mathrm{~s}$ of operation. Results are given for low-sulfur 304 stainless steel (left-hand plot) and high-sulfur 304 stainless steel (right-hand plot) anodes. The temperature interval is $2000 \mathrm{~K}$ in the arc, $200 \mathrm{~K}$ in the tungsten cathode, and $250 \mathrm{~K}$ in the anode. The maximum values of the iron vapour mole fraction are given in each case. Reproduced with permission from John Wiley and Sons [181] 
siarki. W pierwszym przypadku napięcie powierzchniowe maleje wraz ze wzrostem temperatury, a w drugim - wzrasta wraz z temperaturą. W stali o niskiej zawartości siarki efekt Marangoniego prowadzi do przepływu w jeziorku, który wychodzi promieniowo na zewnątrz i osiowo do góry, do centralnego obszaru. Dla stali o wysokiej zawartości siarki przepływ następuje promieniowo do środka, a osiowo w dół do centralnego obszaru. W przypadku stali o wysokiej zawartości siarki jeziorko jest głębsze i promieniowo węższe oraz ma wyższą maksymalną temperaturę, prowadzi to do wyższego stężenia oparów nad centrum jeziorka, ale również do gwałtowniejszego spadku wzdłuż promienia. Wyniki te pokazują, jak duże jest znacznie jeziorka (rys. 18).

Kolejnym potwierdzeniem znaczenia dokładnych pomiarów temperatury jeziorka są obliczenia stężenia oparów żelaza w łuku argonowym i helowym dla anody ze stali nierdzewnej o niskiej zawartości siarki w zależności od czasu [182]. Gdy po zapaleniu łuku temperatura na powierzchni jeziorka wzrasta, stężenie oparów metali również rośnie. Dla łuku argonowego maksymalne stężenie molowe oparów żelaza wzrosło od $0 \div 0,25 \%$ wraz ze wzrostem temperatury z $1800 \div 2200 \mathrm{~K}$. W przypadku łuku helowego stężenie oparów żelaza wzrosło z $4 \%$ do $7 \%$ wraz ze wzrostem temperatury z 2550 do 2700 K. Czynnikiem mającym największy wpływ na stężenie oparów żelaza jest temperatura jeziorka spawalniczego. Stosunkowo mała różnica temperatury może prowadzić do bardzo dużych różnic w stężeniu. Należy zauważyć, że obliczone stężenie w helu jest zgodne ze zmierzonym przez Terasaki (rys. 5 w cz. 1 art.) [27].

Yamamoto badał także powstawanie oparów różnych metali (żelaza, chromu, manganu) z materiału roboczego ze stali nierdzewnej [183]. Osobno badał różne opary metali, nie próbując, jak wpływają na siebie wzajemnie. Wagowy skład stali nierdzewnej wyglądał następująco: $80,5 \%$ Fe, 18\% Cr oraz 1,5\% Mn. Pomimo tego, opary wszystkich trzech metali miały podobne stężenie, przy czym stężenie manganu było najwyższe. Wynika to z jego mniejszego punktu wrzenia, czego skutkiem jest wyższe ciśnienie oparów w temperaturze powierzchni jeziorka.

Iwao przedstawił badania impulsowego procesu GTAW [148]. Spawanie impulsowe umożliwia kontrolę przenoszenia ciepła oraz pozwala zwiększyć prędkości spawania. Wyniki pokazują znaczenie przepływu konwekcyjnego z katody w rozmieszczaniu się oparów metalicznych w łuku. Prędkość przepływu konwekcyjnego jest większa w szczytowych okresach prądu, co powoduje kurczenie się obszaru wraz ze stężeniem oparów żelaza w kierunku anody. Iwao zawarł w swojej pracy także model śledzenia absorpcji promieniowania w plazmie.

Podsumowując, zgodnie z wynikami przeprowadzonych doświadczeń, stężenie oparów metali w spawaniu GTAW, w osłonie argonu jest zazwyczaj małe, nie przekracza 1\%. Do wyjątków należą prace Lago [158] i Gonzaleza [159] dotyczące anody z żelaza, w których przewidywano znacznie wyższe stężenie. Niski poziom oparów metalu prowadzi do wzrostu przewodności elektrycznej w obszarach chłodniejszych poza osią, blisko anody. Prowadzi to do zmniejszenia gęstości prądu oraz gęstości strumienia ciepła blisko centrum anody. Wyższe stężenie oparów metalu prowadzi do strat radiacyjnych. W obu przypadkach temperatura łuku ma tendencję spadkową.

Z powodu wyższej temperatury jeziorka stężenie oparów metalicznych w łuku helowym jest znacznie większe niż w łuku argonowym, przy tym samym prądzie.

Wpływ oparów metalicznych na napięcie łuku zależy od ich stężenia. Jak wspomniano wcześniej, omawiając pracę $\mathrm{Gu}$, widoczne są dwa główne zjawiska, wynikające z zależności przewodności elektrycznej od stężenia oparów metalicznych i temperatury (rys. 7d w cz. 2 art.) [166]. W przypadku niskiego stężenia oparów metali, zwiększona przewodność elektryczna, spowodowana obecnością oparów w niskiej temperaturze, dominuje i napięcie maleje. Przy wysokim stężeniu zwiększona emisja promieniowania chłodzi łuk i zazwyczaj przewodność elektryczna maleje wraz ze spadkiem temperatury, a tym samym napięcie łuku wzrasta.

\section{Modelowanie łuku w procesie GMAW}

W nielicznych pracach na temat modelowania rozpatrywano wpływ oparów metali na łuk GMAW, pomimo znaczących dowodów świadczących o tym, że opary metaliczne mają bardzo znaczny wpływ na właściwości łuku.

Etemadi badał odparowywanie miedzi z górnej elektrody jarzącego się swobodnie łuku [184]. Biegunowość łuku była taka sama jak w spawaniu GTAW, tzn. górna elektroda była katodą. Niemniej jednak, obecność źródła oparów metalicznych na szczycie łuku oznacza, że istnieją silne podobieństwa do spawania GMAW. Założono, że szybkość powstawania oparów wynosiła $1 \mathrm{mg} \cdot \mathrm{s}^{-1}$ począwszy od wierzchołka katody. Użyto współczynnika dyfuzji binarnej, co spowodowało duże zawyżenie prędkości dyfuzji wysokiej temperaturze blisko katody (rys. $10 \mathrm{w}$ cz. 2 art.). Niemniej jednak, przepływ konwekcyjny dominuje w tym obszarze, więc rozkład oparów miedzi powinien być wiarygodny. Poważniejszy problem stanowi pominięcie przez Etemadiego promieniowania z oparów miedzi, ponieważ posłużył się on współczynnikiem emisji promieniowania argonu. Co więcej, wydaje się, że wpływ źródła oparów metali nie był brany pod uwagę w równaniu na zachowanie masy. Autor w swojej pracy przewidział, że przewodność elektryczna wzrośnie z powodu wysokiego stężenia miedzi (między 0,8 udziału masowego na katodzie a 0,15 na anodzie na osi), co doprowadziło do większego zaciskania łuku i tym samym podniosło temperaturę w rdzeniu łuku, ale obniżyło ją na krawędziach. 


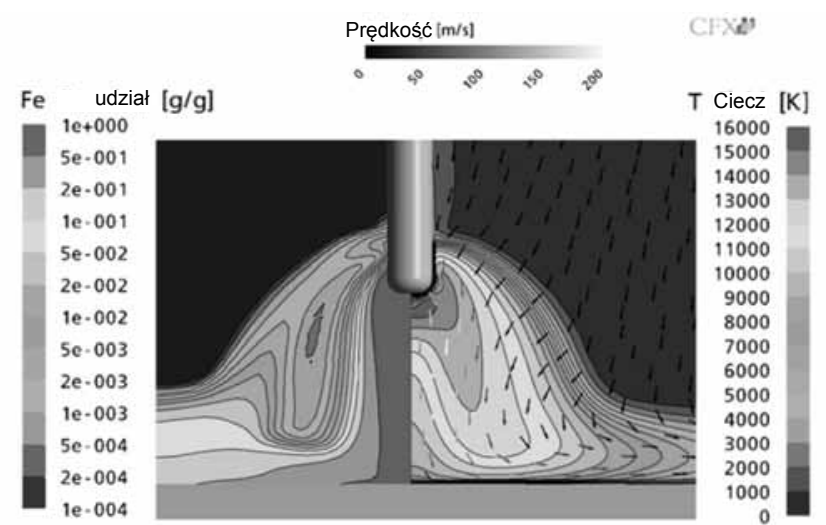

Rys. 19. Rozkład stężenia oparów metalicznych, temperatury oraz wektorów przepływu w łuku argonowym przy 250 A i przy założeniu, że opary żelaza powstały na anodzie drutu przy szybkości $0,015 \mathrm{~g} \mathrm{~s}^{-1}$, odpowiadającej $1 \%$ prędkości podawania drutu. Wymiary złącza: $15 \mathrm{~mm}$ poziomo i $10 \mathrm{~mm}$ pionowo [150]

Fig. 19. Distribution of metal vapour concentration and temperature, and flow vectors, for a $250 \mathrm{~A}$ arc in argon assuming iron vapour is produced at the wire anode at a rate of $0.015 \mathrm{~g} \mathrm{~s}^{-1}$, corresponding to $1 \%$ of the wire metal feed rate. The dimensions are $15 \mathrm{~mm}$ horizontally by $10 \mathrm{~mm}$ vertically [150]

Użycie współczynników emisji promieniowania argonu oznacza, że pominięto znaczące chłodzenie promieniowaniem, spowodowane obecnością miedzi. Ponadto dodatkowe pominięcie członu źródłowego na masę oparów metalicznych w równaniu na zachowanie masy oznacza, że wyniki mogą nie być wiarygodne.

Schnick przedstawił wyniki obliczeń wpływu oparów żelaza w spawaniu łukowym GMAW [150]. Założył stałą prędkość odparowywania anody z drutu, a do równań na ciągłość masy i oparów metali włączył człon źródłowy dla oparów metalu. Posłużył się metodą współczynnika wspólnej dyfuzji, co umożliwiło dokładne obliczenia przenoszenia oparów żelaza w związku z dyfuzją. Silne stężenie oparów żelaza blisko osi łuku pojawiło się z powodu gwałtownego przepływu konwekcyjnego w dół. Zjawiska rozdziału miały wpływ na stężenie oparów metali na obrzeżach łuku i minimalnie w obszarze przejściowym. Najbardziej zaskakującym wynikiem było przewidywanie minimalnej temperatury na osi łuku (rys. 19). Minimalnej temperaturze towarzyszyła minimalna gęstość prądu na osi. Przy obliczaniu założono, że napływ zimnego argonu odbywa się z tą samą szybkością co napływ oparów metalicznych i napływ argonu albo z przewodnością elektryczną, albo współczynnikiem emisji promieniowania mieszaniny argonu i żelaza. Wykazano, że to właśnie intensywna emisja promieniowania przez opary żelaza spowodowała minimalną temperaturę.

Schnick przedstawił analizę wpływu szybkości odparowywania i współczynników emisji promieniowania na wyniki badań [72]. Zastosował te same metody, co w poprzedniej pracy [150]. Wyliczone współczynniki emisji promieniowania dla żelaza różnią się o czynnik ok. 100. Ma to duży wpływ na przewidywane temperatury na osi, ale we wszystkich przypadkach można zaobserwować centralne minimum temperatury przy szybkości odparowywania wynoszącej $1 \%$ prędkości podawania drutu. Jedynie wtedy, kiedy prędkość parowania została obniżona do nierealistycznie niskiego poziomu $0,1 \%$ - centralne minimum temperatury zniknęło. Schnick porównał także przewidywania swoich modeli zarówno z obrazami z szybkiej kamery, jak i temperaturami zmierzonymi przez Zielińską [42]. Okazało się, że możliwe jest uzyskanie dobrej zgodności, jeżeli przyjmie się odpowiednio wysoką szybkość parowania. W szczególności, możliwe jest odtworzenie stożkowatego kształtu centralnego obszaru luminescencyjnego. Interesujące jest, że przy dużej szybkości parowania pojawia się odwrócony przepływ na osi łuku, kierujący się w górę od materiału roboczego wskutek silnego chłodzenia centralnych obszarów łuku.

Haidar wykonał ostatnio obliczenia wpływu oparów żelaza na łuk spawalniczy GMAW [162]. Posłużył się danymi dla anody w kształcie drutu o temperaturze powierzchni otrzymanej z modelowania łuku GMAW w czystym argonie [175]. Szybkość parowania oparów metalu obliczył przy użyciu równania HertzaKnudsena-Langmuira (23). W równaniach na zachowanie masy i zachowanie energii uwzględnił wpływ źródła oparów metalu. Pominął dyfuzję oparów metalu, więc rozkład zostało określony jedynie za pomocą przepływu konwekcyjnego. Wpływ oparów żelaza na emisję promieniowania został także pominięty, dlatego trudności w uzyskaniu zbieżności świadczą o tym, że przepływu i właściwości termodynamiczne w mieszaninach o zawartości oparów żelaza większej niż $25 \%$ przyjęto takie, jak właściwości dla $25 \%$ oparów żelaza. Porównano rozkłady temperatury, w których pominięto źródło oparów żelaza oraz w których wzięto je pod uwagę. W tym drugim przypadku przewidziano minimalną temperaturę na osi. Rozkłady temperatury uzyskane dla plazmy w czystym argonie, ale zawierające źródło zimnego argonu z drutu anody, okazały się podobne do uzyskanych dla plazmy w oparach argonu i żelaza. Odkryto, że to napływ zimnego gazu (niezależnie czy oparów metalicznych, czy argonu) miał największy wpływ na to chłodzenie; jest to więc jeden z najważniejszych efektów.

Pomijanie wpływu oparów metali na emisję promieniowania jest poważnym mankamentem modelu Haidara, ale pomimo tego, zaletą jego pracy jest zakładanie bardziej realistycznych kształtów drutu anody i bezpośrednie obliczanie szybkości parowania. Wyniki potwierdzają wnioski Schnicka, który twierdzi, że opary metali mogą znacząco obniżyć temperaturę centralnego obszaru łuku spawalniczego GMAW [72, 150]. Jednakże twierdzenie Haidara, że napływ zimnego argonu jest ważny, nie zgadza się z wynikami Schnicka, który uważa, że skutki chłodzenia wywołanego napływem zimnego gazu są małe w porównaniu $z$ tymi, jakie wywołuje silna emisja promieniowania z oparów żelaza [72, 150]. Należy zauważyć, że przepływ zimnego gazu użytego przez Haidara w większości jego obliczeń, wynoszący $0,07 \mathrm{~g} \cdot \mathrm{s}^{-1}$, 
jest ok. 5x większy od, użytego przez Schnicka. Analogicznie - udział masowy oparów żelaza jest także większy, osiągając $100 \%$ w niektórych obszarach łuku. Haidar przedstawił również wyniki dla napływu zimnego argonu z szybkością 0,0175 $\mathrm{g} \cdot \mathrm{s}^{-1}$, które są podobne do uzyskanych przez Schnicka. W tym przypadku jednak Haidar dowiódł, że nadal na osi występuje minimum rozkładu temperatury, choć nie jest ono głęboki. Temperatura na osi łuku jest o nie więcej niż $2000 \mathrm{~K}$ mniejsza od temperatury maksymalnej.

Istnieją co najmniej dwa czynniki odpowiedzialne za te rozbieżności. Pierwszym z nich jest pomijanie dyfuzji w modelu Haidara, co prowadzi do zawyżenia chłodzenia. Drugi czynnik to różne rozkłady źródeł oparów żelaza przyjęte w tych dwóch modelach (model Schnicka to tylko oszacowanie). Może to prowadzić do błędnych opisów przepływu w łuku.

Pewne dowody świadczące o znaczeniu rozkładu przepływu zostały przedstawione eksperymentalnie w spawaniu łukowym GTAW w argonie przy prądzie 500 A. W doświadczeniu tym skutki dodatkowego przepływu argonu przez otwór o średnicy $0,8 \mathrm{~mm}$ w katodzie zostały zmierzone spektroskopowo [185]. Dodatkowy przepływ argonu $\left(0,014 \mathrm{~g} \cdot \mathrm{s}^{-1}\right)$ doprowadził do schłodzenia centralnego obszaru łuku. Temperatura, która wynosiła powyżej $20000 \mathrm{~K}$ bez dodatkowego przepływu, spadła poniżej $15000 \mathrm{~K}$ na promieniach poniżej 0,5 mm. Wskutek gwałtownego napływu zimnego gazu zaobserwowano duże odstępstwa od stanu LRT (Lokalna Równowaga Termodynamiczna) w tym obszarze.

Względne skutki bezpośredniego chłodzenia napływu oparów metali $z$ anody oraz promieniowania można porównać do warunków opisanych przez Schnicka [150]. W przypadku szybkości parowania wynoszącej $0,015 \mathrm{~g} \cdot \mathrm{s}^{-1}$, moc potrzebna do odparowania żelaza wynosi $93 \mathrm{~W}$, dodatkowa moc $410 \mathrm{~W}$ jest potrzebna do podgrzania żelaza z punktu wrzenia wynoszącego $3023 \mathrm{~K}$ do $15000 \mathrm{~K}$ (maksymalna temperatura panująca w łuku przy 250 A). Można to porównać z obliczoną emisją promieniowania z łuku wynoszącą $2030 \mathrm{~W}$. W tych warunkach emisja promieniowania dominuje nad efektem chłodzenia napływu oparów. Przy większej szybkości parowania ważniejszy staje się efekt chłodzenia, choć określenie ilościowe nie będzie łatwe, ponieważ większe stężenie oparów metali powoduje wzrost współczynnika emisji promieniowania dla podanej temperatury, a z kolei temperatura łuku będzie niższa, co spowoduje spadek zarówno mocy wymaganej do ogrzania oparów metali, jak i emisji promieniowania.

$\mathrm{Na}$ podstawie danych uzyskanych z modeli łuków spawalniczych GMAW można stwierdzić, że opary metaliczne wydobywające się z anody w kształcie drutu mają bardzo duży wpływ na właściwości łuku. Moga powodować pojawienie się minimum rozkładu temperatury oraz minimum gęstości prądu na osi łuku. Jak można się spodziewać, ten duży spadek temperatury i gęstości prądu będzie miał ogromny wpływ na przepływ ciepła do materiału roboczego, o czym należy pamiętać przy modelowaniu spawania łukowego.

\section{Dymy spawalnicze}

Określenia dymy spawalnicze używa się do opisu małych cząstek i ich skupisk, które powstają podczas spawania łukowego. Cząstki, zazwyczaj o submikrometrowych rozmiarach, są na tyle małe, by utrzymać się w powietrzu. Mogą tym samym dostać się do układu oddechowego człowieka i spowodować problemy zdrowotne. Znacznie więcej dymów powstaje w czasie spawania GMAW niż GTAW.

Dymy powstają w wyniku nukleacji, a następnie wzrostu cząstek z oparów metalicznych w plazmie łuku. Opary metali mogą wydobywać się z jeziorka spawalniczego, z kropli (zarówno przed, jak i po oderwaniu się z drutu elektrody) w spawaniu GMAW oraz z odprysków.

Uznano, że dymy składają się częściowo z małych odpryskowych kropli $[186,187]$. Ponieważ istnieje związek pomiędzy ilością odprysków a szybkością powstawania dymów spawalniczych wraz ze zmianą parametrów dostępne są wyniki wskazujące, że odpryski wywołują 6 $\div 35 \%$ dymów [188], wydaje się mało prawdopodobne, by odpryski mogły mieć znaczący i bezpośredni udział w tworzeniu się dymów. Istotne jest natomiast, że niektóre z kropli odpryskowych są na tyle małe, by móc unosić się w powietrzu i dostać się do układu oddechowego człowieka (mniej niż $20 \mu \mathrm{m}$ ). Przeprowadzone pomiary wskazały, że stężenie kropli odpryskowych jest wiele rzędów wielkości mniejsze od stężenia submikrometrowych cząstek dymów [189].

wybrane wyniki wskazują, że to właśnie gwałtowne utlenianie cząstek odpryskowych tworzy dymy [186, 190]. Ta hipoteza została oparta na podstawie wykrycia kropli odpryskowych, które były porowate i najwidoczniej utlenione. Zaobserwowano również, że lepszy gaz osłonowy łuku redukuje ilość dymów. Jednakże, Jenkins i Eagar przeprowadzili doświadczenia i obliczenia, które wskazały, że jedynie krople odpryskowe większe niż $2 \mathrm{~mm}$ mogą utlenić się i wytwarzać ogromną ilość dymów, a jednocześnie tak duże krople nie tworzą znaczącej części odprysków [191].

Tym bardziej prawdopodobne wydaje się, że duża ilość dymów tworzy się z oparów metalicznych. Opary metali będą wówczas występować w postaci atomów lub jonów w centralnych obszarach łuku o wysokiej temperaturze oraz ulegną krzepnięciu na materiale rodzimym, tym samym nie będą brały udziału w powstawaniu dymów [165]. Deam oszacował, że w zależności od szybkości podawania drutu elektrody, między $16 \%$ a 80\% oparów metalicznych ulegnie kondensacji podczas spawania GMAW [187]. Pozostałe opary w wyniku konwekcji i dyfuzji zostaną przeniesione do chłodniejszych, krańcowych obszarów łuku. Kiedy wraz z temperaturą ciśnienie pary nasyconej oparów gwałtownie maleje, opary metali stają się przesycone i zachodzi nukleacja, powodując tworzenie nanocząstek metali. W obecności tlenu molekuły tlenków metalu mogą również powstawać w fazie gazowej, a następnie nukleować, powodując powstawanie nanocząstek tlenków 
metalu. Te nanocząstki wzrastają przez kondensację i w wyniku kolizji tworzą większe cząstki lub ich łańcuchy. Utlenianie pojawia się na pewnym etapie całego procesu, więc dymy zazwyczaj składają się z tlenków metalu.

Cząstki dymów mają średnicę aerodynamiczną poniżej $500 \mathrm{~nm}$, przez co zachodzi duże prawdopodobieństwo odkładania się ich w tych częściach płuc, gdzie szybki mechanizm oczyszczania nie jest efektywny. Skład chemiczny zależy od spawanych stopów. W przypadku stali nierdzewnej głównymi składnikami są tlenki żelaza, chromu, manganu i niklu. Wykazano, że wszystkie składniki dymów mają negatywny wpływ na zdrowie, jednak chrom (zwłaszcza sześciowartościowy) oraz nikiel są szczególnie niebezpieczne [192].

Dostępna jest literatura na temat wpływu dymów na zdrowie człowieka, włączając w to wiele badań epidemiologicznych oraz na zwierzętach i opracowań przeglądowych [192, 193]. Prezentowane są również badania na temat ograniczenia ekspozycji oraz zmiany parametrów w procesie spawania, składu gazu osłonowego, wentylacji, projektu i składu chemicznego elektrod, itp. [186, 193, 194].

Wyniki obliczeń prędkości powstawania dymów spawalniczych są podstawowe. W znacznej części zawierają oszacowania inżynieryjne dotyczące temperatury kropli oraz szybkości parowania (np. [187, 188, 195]). Haidar rozwinął spójny, dwuwymiarowy model obliczeniowy powstawania kropli w GMAW, umożliwiający przewidywanie kształtu kropli i temperatury, co z kolei pozwala na oszacowanie szybkości parowania [175].

Tashiro natomiast zrobił ogromny postęp w tworzeniu modeli powstawania dymów [196]. Posłużył się on dwuwymiarowymi obliczeniowymi modelami GMAW i GTAW, by określić temperaturę jeziorka spawalniczego, a w GMAW temperaturę kropli. Umożliwiło to określenie stężenia oparów w łuku. Posłużył się również dwuwymiarowym podmodelem śledzącym nukleację nano-cząstek z oparów, a następnie kondensację oparów w cząstki i kolizji cząstek. Istotne jest, że podejście to pozwala na rozróżnienie pomiędzy koalescencją (tworzeniem większej cząstki) a aglomeracją (tworzeniem łańcucha osobnych cząstek) zderzających się cząstek. Takie podejście umożliwia przewidywanie rozmiaru i kształtu cząstek dymów powstałych w różnych obszarach łuku. Przewidywania porównano z wynikam pomiarów cząstek dymu i otrzymano w miarę dobrą zgodność.

Istnieje jeszcze wiele „ulepszeń”, które można by wprowadzić do przyszłych badań. Przykładem może być włączenie do modelu reakcji utleniania lub rozróżniania pomiędzy koalescencją i aglomeracją w zależności od tego czy temperatura jest powyżej, czy poniżej temperatury topnienia przy uwzględnieniu skutków dyfuzji w stanie stałym [197]. Niemniej, praca Tashiro jest znaczącym krokiem w kierunku całkowitego zrozumienia procesu powstawania dymów spawalniczych z oparów metali [196].

\section{Omówienie i wnioski}

Powstawanie oparów metali jest bardzo ważnym zjawiskiem w procesie spawania łukowego. Udany proces spawania zależy od topienia materiału rodzimego, co oczywiście spowoduje powstanie choćby niewielkiej ilości oparów metalicznych. Ilość oparów będzie jednak zależeć od temperatury i powierzchni jeziorka spawalniczego zarówno w spawaniu GTAW, jak i GMAW, a także od drutu elektrody i kropli w GMAW. llość oparów można zredukować przez obniżanie natężenia prądu łuku i zmienianie innych parametrów, co spowoduje obniżenie temperatury stopionych obszarów metalu. Takie działanie powoduje jednak obniżenie efektywności spawania.

Pomiary i obliczenia wskazują, że opary metali mają większy wpływ na spawanie GMAW niż GTAW. Są ku temu dwa powody. Po pierwsze, spowodowane jest to faktem, że wierzchołek drutu elektrody i krople znajdują się w wyższej temperaturze niż jeziorko spawalnicze, a wykładnicza zależność ciśnienia oparów od temperatury prowadzi do większego stężenia oparów metalu. Po drugie, silny przepływ konwekcyjny z drutu elektrody oznacza, że opary metali są silnie skoncentrowane w obszarach centralnych łuku. W przeciwieństwie do tego, przepływ blisko jeziorka jest przeważnie bezpośrednio skierowany promieniowo na zewnątrz, więc stężenie oparów metalicznych pochodzących z jeziorka spawalniczego zazwyczaj występuje $z$ dala od centralnych obszarów.

W konsekwencji zróżnicowania w stężeniu i rozkładzie oparów metali w GMAW i GTAW, znaczenie mechanizmów fizycznych, przez które opary wpływają na właściwości łuku, także się różni. Jak wspomniano, nawet niskie stężenie oparów metali ma duży wpływ na dwie termofizyczne właściwości: współczynnik emisji promieniowania i przewodność elektryczną. Wpływ na przewodność elektryczną jest najważniejszy w niskiej temperaturze, w szczególności nawet $1 \%$ oparów metali oznacza, że plazma będzie przewodzić w temperaturze zaledwie $4000 \mathrm{~K}$ - bardziej niż $7000 \mathrm{~K}$ dla plazmy w argonie. To znaczy, że główny wpływ oparów metali powstałych w GTAW (które zazwyczaj obecne są w obszarach blisko anody, gdzie jest niższa temperatura) zwiększa obszary przewodności do wyższego promienia. Ma to wpływ na obniżenie gęstości prądu i tym samym gęstości przepływu ciepła blisko centrum anody.

Opary metali zwiększają współczynnik emisji promieniowania we wszystkich wartościach temperatury obserwowanych w łuku, a wzrost ten jest w przybliżeniu proporcjonalny do stężenia oparów metali. Zatem główny wpływ oparów w GMAW to wzrost emisji promieniowania z centralnych obszarów łuku, a tym samym ochłodzenie tego obszaru. Prowadzi to do powstania charakterystycznego wyglądu łuku w GMAW, jaki można zobaczyć na rysunku 3 (cz. 1 arty.), w którym jasny centralny obszar zdominowany przez promieniowanie oparów metali otoczony jest argonem, mającym nawet wyższą temperaturę niż obszar centralny. 
Obecność oparów metali zazwyczaj prowadzi do spadku temperatury łuku, co jest spowodowane zarówno wzrostem przewodności elektrycznej, jak i wzrostem emisji promieniowania. Wpływ oparów na napięcie łuku, jak wcześniej wskazano, nie jest do końca jasny. Zwiększona przewodność elektryczna prowadzi zazwyczaj do zmniejszenia napięcia, ale spadek temperatury związany $z$ silną emisją promieniowania przynosi przeciwny efekt (ponieważ przewodność zwiększa temperaturę). Jak pokazano na rysunku 16 , napięcie ma tendencję spadkową w przypadku niskiego stężenia oparów metali oraz może wzrastać przy większym stężeniu.

Pomimo tego, że najważniejsze skutki obecności oparów metali w łukach spawalniczych są w zasadzie dobrze znane, to nadal pozostaje do wyjaśnienia wiele kwestii.

Na polu doświadczalnym istnieje cały czas ogromne pole do dalszych badań, zwłaszcza jeśli chodzi o łuk GMAW. Cały czas pozostaje nierozwiązana kwestia stężenia oparów metali. Valensi [46] mierzył stężenie wynoszące poniżej $1 \% \mathrm{w}$ przeciwieństwie do znacznie większego, jakie wyznaczyli Goecke [50] i Rouffet [44], oraz stężeń przewidzianych w modelach $[72,150,162,184]$. Wpływ, jaki może mieć skład gazu osłonowego na stężenie oparów metali, także wymaga dalszych badań. Pomiary wskazują, że napięcie początkowo spada, kiedy dwutlenek węgla jest dodany do argonu, ale następnie podnosi się, wraz ze wzrostem stężenia dwutlenku węgla. Może mieć to związek ze zmianami w stężeniach oparów metali, ale jako mechanizm sugerowano także powstawanie izolacyjnej warstwy na powierzchni elektrody [46, 49].

Nie jest pewne, czy w centralnym obszarze zdominowanym przez opary metaliczne występuje LRT. Istnieją pewne dowody na to, że gwałtowny przepływ oparów w ten obszar prowadzi do odstępstw od LRT. Potrzebne są dalsze badania przy użyciu technik, które nie wymagają obecności LRT, takich jak rozpraszanie laserowe czy metody spektroskopowe oparte na poszerzeniu linii widmowych.

Opracowano bardzo wiele różnych procesów spawalniczych GMAW i GTAW (DC, AC, pulsujący, krótkiego łuku, różnej biegunowości) i dopiero ostatnio poczyniono wysiłki w celu lepszego zrozumienia roli oparów metalu $w$ wielu $z$ tych procesów. Istnieje również ogromna różnorodność w składzie drutu $z$ różnymi stopami stali, różnymi metalami i drutami z rdzeniem $z$ tlenkami itp. Przeprowadzono natomiast bardzo mało badań na temat wpływu składu drutu na powstanie oparów metalicznych, np. nadal nie jest wyjaśniony wpływ oparów metali lekkich w spawaniu GMAW. Tylko w jednej pracy dowiedziono, że nie pojawia się żadne minimum rozkładu temperatury, jeśli użyta jest anoda $z$ drutu aluminiowego [70].

Pojawia się także pytanie, od którego momentu opary metali zaczynają mieć istotny wpływ na właściwości łuku. W jednej pracy dotyczącej łuku spawalniczego GTAW podjęto próbę wyjaśnienia tej kwestii, ale bez wyraźnych rezultatów [65]. Cenne byłoby tutaj dokładne zbadanie, jaki wpływ ma natężenie prądu w łuku i inne parametry na rozkład oparów metali i temperaturę.

Pomimo że przeprowadzono wiele badań polegających na modelowaniu, w których badano wpływ oparów metali w łukach spawalniczych, to nie zostały opublikowane żadne konkretne prace. Idealny model wymagałby dokładnych obliczeń członu źródłowego oparów metali, dyfuzji oparów w plazmie oraz wpływu oparów metali na właściwości termodynamiczne plazmy. Wszystkie te kwestie zostały wcześniej szczegółowo omówione. Teraz podsumowane zostaną tylko najważniejsze.

Określenie członu źródłowego oparów metali jest zasadnicze w obliczaniu ilości oparów w łuku. Wymagane są przy tym: dokładne określenie temperatury powierzchni obszarów ciekłego metalu oraz określenie szybkości odparowywania przy podanych wartościach temperatury. Sama temperatura jest funkcją szybkości odparowywania przez wpływ parowania chłodzącego (w obu przypadkach bezpośrednio, a w przypadku GMAW - przez przekaz energii do jeziorka przez krople). Jak już wspomniano w części 2, aby określić temperaturę ciekłego metalu, potrzebne są: spójny model łuku i elektrod, który uwzględnia przepływ płynu w jeziorku, a w przypadku GMAW - kształt kropli. Zwykłe metody służące do określenia szybkości powstawania oparów oparte są na warunkach granicznych wyznaczonych na podstawie ciśnienia oparów ciekłego metalu na granicy między metalem a plazmą lub wykorzystujące obliczenia wynikające wprost $z$ równania Hertza-Langmuira-Knudsena. Zaletą tej drugiej metody jest to, że umożliwia ona określenie członów źródłowych wymaganych w równaniach na zachowanie masy i energii. Jak wykazał Haidar, jest to ważne w przypadku dużej szybkości parowania w spawaniu GMAW [162], choć będzie to mniej znaczące w spawaniu GTAW. W części 2 wspomniano o tym, że równanie Hertza-Langmuira-Knudsena jest jedynie przybliżeniem i aby lepiej zrozumieć obszar graniczny, należy stworzyć lepszy model.

Dyfuzja oparów metali jest najlepiej uwzględniona przy użyciu metody współczynnika połączonej dyfuzji, która jest równoważna pełnemu wieloskładnikowemu podejściu przy założeniu stanu LRT. Jak pokazano w części 2 artykułu, inne metody są niedokładne i dlatego dają tylko przybliżone wyniki. Może to być częściowo uzasadnione, jeśli konwekcja jest dominującym mechanizmem przenoszenia, jak ma to miejsce w obszarze centralnym łuku w spawaniu GMAW. Niemniej jednak, metoda połączonego współczynnika dyfuzji jest niewiele trudniejsza do zastosowania niż metody przybliżone, więc nie ma powodu, by jej nie stosować.

W części 2 artykułu, podane w literaturze wartości właściwości termodynamicznych i przenoszenia są zazwyczaj bardzo spójne. Istnieją możliwości poprawienia dokładności współczynników przenoszenia dzięki zastosowaniu dokładniejszych potencjałów intermolekularnych, ale nie jest to główne 
źródło występowania niedokładności w modelach obliczeniowych. Bardziej znaczące są rozbieżności pomiędzy współczynnikami emisji promieniowania podanymi w literaturze, wynoszą więcej niż jeden rząd wielkości (rys. 15 w cz. 2 arty.). Schnick wykazał, że różne wartości mają duży wpływ na obliczoną temperaturę w łuku spawalniczym GMAW [72]. W łuku spawalniczym GTAW skutki tych rozbieżności będą słabsze, ponieważ promieniowanie nie jest tak istotną kwestią. Iwao pokazał, że samoabsorpcja promieniowania może być ważna przy użyciu metod uproszczonych, tak więc warto byłoby zastosować metodę bardziej wyszukaną, np. metodę charakterystyk częściowych [148].

Ostatnia kwestia dotyczy usunięcia oparów metali z plazmy łukowej. Opary mogą być przenoszone na obrzeża, mogą nukeować i kondensować, tworząc cząstki stałe (dymy spawalnicze) lub mogą ponownie skondensować się na elektrodzie. Badania dotyczące tworzenia się dymów pokazują, że duże cząstki metali odkładane są na elektrodach (np. [165,187]). Nie powstał do tej pory model obliczeniowy, który w pełni odpowiadałby na pytanie, jak najlepiej sobie z tym poradzić. Haidar zakładał, że wszystkie opary metali w GMAW, które szybko dotarły do obszaru powyżej materiału roboczego - były skondensowane [162].

\section{Literatura}

[5] Tanaka M., Lowke J. J.: Predictions of weld pool profiles using plasma physics, J. Phys. D: Appl. Phys.40 R I-24 (2007).

[27] Terasaki H., Tanaka M., Ushio M.: Effects of metal vapor on electron temperature in helium gas tungsten arcs, Metall. Mater. Trans. A 33 1183-8 (2002).

[42] Zielińska S., Musioł K., Dzierżęga K., Pellerin S., Valensi F., de Izarra C., Briand F.: Investigations of GMAW plasma by optical emission spectroscopy, Plasma Sources Sci. Technol. 16 832-8 (2007).

[44] Rouffet M. E., Wendt M., Goett G., Kozakov R., Schoepp H., Weltmann K. D., Uhrlandt D.: Spectroscopic investigation of the high-current phase of a pulsed GMAW.

[46] Valensi F., Pellerin S., Boutaghane A., Dzierżęga K., Zielińska S., Pellerin N., Briand F.: Plasma diagnostic in gas metal arc welding by optical emission spectroscopy, J. Phys. D: Appl. Phys. 43434002 (2010).

[49] Zielińska S., Pellerin S., Valensi F., Dzierżęga K., Musioł K., de Izarra C., Briand F., Eur. Phys. J. Appl. Phys. 43 111-22 (2008).

[50] Goecke S. F., Metzke E., Spille-Kohoff A., Langula M.: ChopArc. MSG-Lichtbogenschweissen für den Ultraleichtbau, Stuttgart, Fraunhofer IRB Verlag (2005)

[63] Gonzalez J. J., Bouaziz M., Razafinimanana M., Gleizes A.: The influence of iron vapour on an argon transferred arc, Plasma Sources Sci. Technol. 6 20-8 (1997).

[65] Farmer A. J. D., Haddad G. N., Cram L. E.: Temperature determinations in a free-burning arc: III. Measurements with molten anodes, J. Phys. D: Appl. Phys. 19 1723-30 (1986)

[70] Smars E. A., Acinger K.: Material transport and temperature distribution in arc between melting aluminium electrodes, Document No 212-162-68, International Institute of Welding (1968).

[72] Schnick M., Füssel U., Hertel M., Haessler M., Spille-Kohoff A., Murphy A. B.: Modelling of gas-metal arc welding taking into account metal vapour, J. Phys. D: Appl. Phys. 43 434008 (2010).

[84] Murphy A. B.: Thermal plasmas in gas mixtures, J. Phys. D: Appl. Phys. 34 R151-73 (2001).
Takie podejście jest przydatne, ale wymaga jeszcze udoskonalenia, jeśli zakładamy, że jeziorko jest ciekłe. Praca Tashiro dotycząca powstawania dymów spawalniczych sugeruje metody, w których oblicza się usunięcie oparów przez nukleację i następnie kondensację na cząstkach stałych [196].

Podsumowując, powstawanie, przenoszenie i usuwanie oparów metali w łukach spawalniczych są tematami, które przyciągnęły uwagę wielu badaczy. W przeszłości koncentrowano się głównie na GTAW, jednak postępy, jakie w ostatnich latach dokonały się na polu doświadczalnym, obliczeniowym i teoretycznym pozwoliły podjąć wyzwanie, jakim jest spawanie GMAW. Jest jeszcze wiele kwestii do rozwiązania, jedną z najważniejszych jest stężenie oparów metali w łuku spawalniczym GMAW. Ponieważ obecność oparów metali ma wpływ na przenoszenia ładunku i energii do jeziorka, ma też czasem bardzo duży wpływ na jego głębokość i kształt.

Przegląd, którego tutaj dokonano, miał za zadanie wskazać główne wyniki przeprowadzonych badań, mankamenty zastosowanych do tej pory technik oraz pokazać obszary, które wymagają dalszych badań. Możliwe, że niniejsze opracowanie zachęci do dalszych prac w tej dziedzinie.

[109] Gu L., Arntsberg A. E., Bakken J. A.: The influence of silicon vapour on the transport coefficients and the arc behaviour in an argon plasma, Proc. 10th Int. Symp. Plasma Chemistry ed, U. Ehlemann et al, paper 1.1-6, Bochum, Germany, 4-9 August 1991.

[129] Gu L., Jensen R., Arntsberg A.E., Bakken J. A.: Study on silicon vapour contaminated argon arcs and the metal pools, Proc. 11th Int. Symp. Plasma Chemistry, (Loughborough, UK, 22-27 August 1993), ed. J.E. Harry s. 222-7(1993).

[130] Bakken J. A.: Modelling of fluid flow, heat transfer and diffusion in arcs, J. High Temp. Chem. Process. 3 677-88 (1994).

[134] Murphy A .B., Boulos M. I., Colombo V., Fauchais P., Ghedini E., Gleizes A., Mostaghimi J., Proulx P., Schram D. C.: Advanced thermal plasma modelling, High Temp. Mater. Process. 12 255-336 (2008).

[138] Cram L. E.: Statistical evaluation of radiative power losses from thermal plasmas due to spectral lines, J. Phys. D: Appl. Phys. 18 401-11 (1985).

[148] Iwao T., Mori Y., Okubo M., Sakai T., Tashiro S., Tanaka M., Yumoto M.: Modelling of metal vapor in pulse TIG including influence of self-absorption, J. Phys. D: Appl. Phys. 43 434010 (2010).

[149] Tashiro S., Tanaka M., Nakata K., Iwao T., Koshiishi F., Suzuki K., Yamazaki K.: Plasma properties of helium gas tungsten arc with metal vapour, Sci. Technol. Weld. Join. 12 202-7 (2007).

[150] Schnick M., Füssel U., Hertel M., Spille-Kohoff A., Murphy A. B.: Metal vapour causes a central minimumin arc temperature in gas-metal arc welding through increased radiative emission, J. Phys. D: Appl. Phys. 43 022001(2010).

[156] Menart J., Lin L.: Numerical study of a free burning argon arc with copper contamination from the anode, Plasma Chem. Plasma Process. 19 153-70 (1999).

[157] Zhao G. Y., Dassanayabe M., Etemadi K.: Numerical simulation of a free-burning argon arc with copper evaporation from the anode, Plasma Chem. Plasma Process. 10 87-99 (1990). 
[158] Lago F., Gonzalez J. J., Freton P., Gleizes A.: A numerical modelling of an electric arc and its interaction with the anode: I. The two-dimensional model, J. Phys. D: Appl. Phys. 37 883-97 (2004).

[159] Gonzalez J. J., Gleizes A., Proulx P., Boulos M.: Mathematical modelling of a free-burning arc in the presence of metal vapor, J. Appl. Phys. 74 3065-70 (1993).

[160] Yamamoto K., Tanaka M., Tashiro S., Nakata K., Yamazaki K.,Yamamoto E., Suzuki K., Murphy A. B.: Metal vapour behaviour in thermal plasma of gas tungsten arcs during welding, Sci. Technol. Weld. Join. 13 566-72 (2008).

[161] Yamamoto K., Tanaka M., Tashiro S., Nakata K., Yamazaki K., Yamamoto E., Suzuki K., Murphy A. B.: Numerical simulation of metal vapor behavior in arc plasma, Surf. Coat. Technol. 202 5302-5 (2008).

[162] Haidar J.: The dynamic effects of metal vapour in gas metal arc welding, J. Phys. D: Appl. Phys. 43165204 (2010).

[165] Haidar J.: An analysis of heat transfer and fume production in gas metal arc welding. III, J. Appl. Phys. 85 3448-59 (1999).

[166] Gu L., Arntsberg A. E., Bakken J. A.: DC arc behaviour in mixtures of argon and metal (Si) vapour from a liquid metal anode, J. High Temp. Chem. Process. 1 (Suplement do nr. 3) 350-7 (1992).

[174] Voller V. R., Prakash C.: A fixed grid numerical modelling methodology for convection-diffusion mushy region phase-change problems, Int. J. Heat Mass Transfer 30 1709-19 (1987).

[175] Haidar J.: An analysis of the formation of metal droplets in arc welding, J. Phys. D: Appl. Phys. 31 1233-44 (1998).

[176] Wang F., Hou W. K., Hu S. J., Kannatey-Asibu E., Schultz W. W., Wang P. C.: Modelling and analysis of metal transfer in gas metal arc welding, J. Phys. D: Appl. Phys. 36 1143-52 (2003).

[177] Fan H. G., Kovacevic R.: A unified model of transport phenomena in gas metal arc welding including electrode, arc plasma and molten pool, J. Phys. D: Appl. Phys. 37 2531-44 (2004).

[178] Hu J., Tsai H. L.: Heat and mass transfer in gas metal arc welding: II. The metal, Int. J. Heat Mass Transf. 50 808-20 (2007).

[179] Hu J., Tsai H. L.: Heat and mass transfer in gas metal arc weIding: I. The arc, Int. J. Heat Mass Transf. 50 833-46 (2007).

[180] Gleizes A., Gonzalez J. J., Freton P.: Thermal plasma modelling, J. Phys. D: Appl. Phys. 38 R153-83 (2005).

[181] Yamamoto K., Tanaka M., Tashiro S., Nakata K., Murphy A. B.: Metal vapor behaviour in GTA welding of a stainless steel considering the Marangoni effect, IEEJ Trans. Electric. Electron. Eng. 4 497-503 (2009).

[182] Tanaka M., Yamamoto K., Tashiro S., Nakata K., Yamamoto E., Yamazaki K., Suzuki K., Murphy A. B., Lowke J. J.: Timedependent calculations of molten pool formation and thermal plasma with metal vapour in gas tungsten arc welding, J. Phys. D: Appl. Phys. 43434009 (2010).
[183] Yamamoto K., Tanaka M., Tashiro S., Nakata K., Yamamoto E., Yamazaki K., Suzuki K., Murphy A. B., Lowke J. J.: Numerical simulation of diffusion of multiple metal vapours in a TIG arc plasma for welding of stainless steel, Weld. World 53 R166-70 (2009).

[184] Etemadi K., Zhao G. Y., Mostaghimi J.: Impact of cathode evaporation on a free-burning arc, J. Phys. D: Appl. Phys. 22 1692-6 (1989).

[185] Haidar J.: Local thermodynamic equilibrium in the cathode region of a free-burning arc in argon, J. Phys. D: Appl. Phys. 28 2494-504 (1995).

[186] Gray C. N., Hewitt P. J., Dare P. R.M.: New approach would help control weld fumes at source: II. MIG fumes, Weld. Met. Fabr. 50 393-7 (1982).

[187] Deam R. T., Simpson S. W., Haidar J.: A semi-empirical model of the fume formation from gas metal arc welding, J. Phys. D: Appl. Phys. 33 1393-402 (2000).

[188] Dennis J. H., Hewitt P. J., Redding C. A. J., Workman A. D.: A model for prediction of fume formation rate in gas metal arc welding (GMAW), globular and spray modes, DC electrode positive, Ann. Occup. Hyg. 45 105-13 (2001).

[189] Zimmer A. T., Baron P. A., Biswas P.: The influence of operating parameters on number-weighted aerosol size distribution generated from a gas metal arc welding process, J. Aerosol Sci. 33 519-31 (2002).

[190] Hewitt P. J., Hirst A.A.: Development and validation of a model to predict the metallic composition of flux cored arc welding fumes, Ann. Occup. Hyg. 35 223-32 (1991).

[191] Jenkins N. T., Eagar T. W.: Fume formation from spatter oxidation during arc welding, Sci. Technol. Weld. Join. 10 537-43 (2005).

[192] Antonini J. M.: Health effects of welding, Crit. Rev. Toxicol. 33 61-103 (2003).

[193] Hewitt P. J.: Occupational health in metal arc welding, Indoor Built Environ. 5 253-62 (1996).

[194] Dennis J. H., French M. J., Hewitt P. J., Mortazavi S. B., Redding C. A. J.: Control of exposure to hexavalent chromium and ozone in gas metal arc welding of stainless steels by use of a secondary shield gas, Ann. Occup. Hyg. 46 43-8 (2002).

[195] loffe I., MacLean D., Perelman N., Stares I., Thornton M.: Fume formation rate at globular to spray mode transition during welding, J. Phys. D: Appl. Phys. 28 2473-7 (1995).

[196] Tashiro S., Zeniya T., Yamamoto K., Tanaka M., Nakata K., Murphy A. B., Yamamoto E., Yamazaki K., Suzuki K.: Numerical analysis of fume formation mechanism in arc, J. Phys. D: Appl. Phys. 43434012 (2010).

[197] Windeler R. S., Lehtinen K. E. J., Friedlander S. K.: Production of nanometer-sized metal oxide particles by gas phase reaction in a free jet: II. Particle size and neck formation-comparison with theory, Aerosol Sci. Technol. 27 191-205 (1997).

[198] Pentegov I.V., Pismiennyj A.S., Petrienko O.I.: Obliczanie parametrów zmechanizowanego spawania stali w osłonie gazów Nr 7 /2010 s. 33-38.

\section{Podziękowania}

Autor dziękuje Dr. Jawadowi Haidarowi i Dr. Johnowi Lowke z CSIRO, Dr. Michaelowi Schnickowi z Uniwersytetu Technicznego w Dresden oraz Profesorowi Manabu Tanace z uniwersytetu w Osace za wiele przydatnych dyskusji. Autor jest także wdzięczny Dr. Vladimirowi Aubrechtowi z Uniwersytetu Technicznego w Brnie za zgodę na użycie jego niepublikowanych danych na temat promieniowania oparów mieszanin argonu i żelaza.

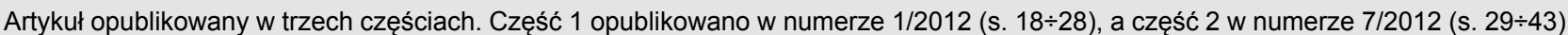

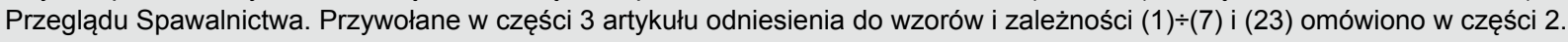

Artykuł za zgodą autora i wydawcy został przedrukowany z Journal of Physics D: Aplied Physics Vol. 43 (2010) s. 8-31 Prawa autorskie do artykułu posiada wydawca IOP Publishing Ltd, Dirac House, Temper Back, BRISTOL, BS1 6BE.

Z języka angielskiego tłumaczyła Aleksandra Pytel (Koszalin). Korektę tłumaczenia wykonał Witold Zawadzki (Uniwersytet Jagielloński, Kraków). 